\title{
Feeding, Nutrition and Sustainability in Dairy Enterprises: The Case of Mediterranean Buffaloes (Bubalus bubalis)
}

\author{
Emilio Sabia, Fabio Napolitano, Salvatore Claps, Ada Braghieri, \\ Nicoletta Piazzolla, and Corrado Pacelli
}

\begin{abstract}
Buffalo farming is a dairy enterprise emerging in Italy and other European and non-European countries due to the progressive saturation of the dairy market, which requires product diversification. As a response to the increasing demand for dairy buffalo products, most farms are undertaking a progressive intensification of rearing techniques. In particular, feeding rely on different rations according to the physiological stage of the animals. Buffalo heifers are generally offered a total mixed ration based on corn silage and ryegrass hay, which require high amounts of water, chemical fertilisers and fossil fuel. Additionally, lactating buffaloes receive concentrates with an even higher environmental impact, whereas more fibrous feeds are used in the dry period. Although the emission factors for enteric fermentation and manure management in buffaloes appear to be $38.4 \%$ and $20.5 \%$ less than in dairy cows, respectively, the contribution of dairy buffalo farms to global warming has been estimated as higher than that produced by dairy cow farms. Therefore, studies are needed to assess the general environmental impact of this species and identify alternative environmental friendly rearing techniques.
\end{abstract}

\section{Introduction}

The water buffalo (Bubalis bubalis) is a large bovid spread throughout the world, especially in Asia and in tropical and subtropical regions. The water buffalo population in the world is about 199 million, more than $80 \%$ placed in Southeast

\footnotetext{
E. Sabia $(\bowtie) \cdot$ S. Claps

Consiglio per la ricerca in agricoltura e l'analisi dell'economia agraria, Research Unit for the Extensive Animal Husbandry (CRA-ZOE), Via Appia Bella Scalo, 85054 Muro Lucano, Italy e-mail: emilio.sabia@entecra.it; salvatore.claps@entecra.it

F. Napolitano • A. Braghieri • N. Piazzolla • C. Pacelli Scuola di Scienze Agrarie, Forestali, Alimentari ed Ambientali, Università degli Studi della Basilicata, Via dell'Ateneo Lucano 10, 85100 Potenza, Italy

e-mail: fabio.napolitano@unibas.it; ada.braghieri@unibas.it; nicolettapiazzolla@libero.it; corrado.pacelli@unibas.it
} 
Table 1 Number of heads and milk production of buffaloes kept in the Mediterranean area

\begin{tabular}{l|l|l}
\hline Countries & Head & Milk Ton \\
\hline Albania & 120 & 10 \\
\hline Bulgaria & 9,212 & 8,081 \\
\hline Egypt & $4,200,000$ & $2,650,000$ \\
\hline Germany & 5,000 & Unknown \\
\hline Greece & 1,750 & 160 \\
\hline Italy & 402,659 & 192,455 \\
\hline Turkey & 107,435 & 4,6989 \\
\hline Total & $4,726,176$ & $2,897,695$ \\
\hline
\end{tabular}

FAOSTAT (2013)

Asia (FAOSTAT 2013). According to genetic, morphological and productive differences, two types of water buffalo may be recognised: the swamp buffalo, from Assam in the west, through Southeast Asia to China in the east, used mostly as draft power and as a meat source, and the river buffalo, characterised by high milk yield and more intensive genetic selection, reared in Indian and Mediterranean regions. The total number of animals raised in Mediterranean area is about 4.7 million, representing $2.4 \%$ of the world population. In Egypt there are 4.2 million buffaloes (Table 1), with a milk production of about 2.6 million ton (FAOSTAT 2013), that are mainly used for direct consumption as Egyptians prefers buffalo milk than cow milk for its stronger sensory properties despite the higher price (Helal and Lasheen 2008). European buffaloes, named Mediterranean buffalo, are all of the river type and are found in Italy, Romania, Bulgaria, Greece, Albania, Kosovo and Republic of Macedonia, and a few hundred in the United Kingdom, Germany, the Netherlands, Switzerland and Hungary (Table 1). Italian buffaloes are 402,000, with a milk production of about 192,000 tons (Table 1), processed into Mozzarella cheese. In Italy buffaloes were particularly selected and officially recognised as Mediterranean Italian breed in 2000. The largest amount of heads is concentrated in Campania (Caserta and Salerno), although many buffalo farms may be found in Latium (Latina and Frosinone provinces) and in Apulia.

The Italian buffalo herd increased to about $52 \%$ from 2005 to 2013, due to the increasing economic interest for its typical cheese, called "Mozzarella di Bufala Campana", which in 1996 was recognised by the Protected Designation of Origin (PDO), at European level. The average annual production of Mozzarella is about $37,000 \mathrm{t}$, mainly consumed in Italy. In recent years, other dairy products, such as ricotta and caciocavallo, have acquired the interest of consumers. The increasing demand of products of buffalo origin may be attributed to the progressive saturation of the dairy market, which requires product diversification.

The aim of the present chapter is to briefly describe the main features of modern buffalo farming techniques and identify weaknesses and strengths in terms of environmental sustainability. 


\section{Farming and Feeding Systems}

The Italian buffalo farming system in Italy has changed from the extensive use of meadows and pastures to intensive farming, with loose housing (e.g. cubicles) and milking routine (machine milking twice a day) similar to dairy cattle.

As to reproduction, natural mating is still the most common practice. However, efforts by the National Association of Buffalo Breeders (ANASB) aim to spread the use of biotechnologies, such as artificial insemination and embryo transfer, for a more accurate and effective genetic improvement of the breed. At our latitudes, buffaloes can be considered seasonal animals and an increasing length of daylight negatively affects their reproductive performances. In fact, about $90 \%$ of calvings are concentrated in late summer and at beginning of autumn. Consequently, the production of milk and mozzarella is concentrated in the cold months, while in Italy most of the market demand for mozzarella cheese is concentrated in summer. In order to reverse the calving season, the out-of-breeding-season-mating technique may be gradually introduced (Zicarelli 1997). It consists in removing bulls from the herd in October and releasing them again in the herd between March and the end of September so that most of parturitions occur between the end of January and the beginning of August.

The feeding system of dairy buffaloes is intensive and similar to dairy cow feeding. Most of farms are organised with three feeding rations, according to the buffalo physiological state: lactation period, dry period and heifer growth period. The forage ration used for the lactation phase and for heifer growth is usually based on farm production of corn silage. The forages are composed for $60 \%$ by corn silage and ryegrass hay. The cultivation of 1 ha of maize for animal feed requires approximately $5,000 \mathrm{~m}^{3}$ of water and about $300 \mathrm{~kg}$ of urea and $100 \mathrm{~kg}$ of $\mathrm{P}_{2} \mathrm{O}_{5}$ as fertilisers, with relevant consequences on water footprint and environmental impact. Ryegrass (Lolium multiflorum L.) for hay production is the crop commonly used in succession to corn in buffalo farming. The concentrates are largely used only during the lactation phase. The unifeed technique, which provides all the dietary components mixed together in one feed using mixing wagons, is widely adopted for buffalo feeding. Grazing practices are not widespread due to the poor availability of optimal pastures in terms of quantity and quality. However, a recent study has shown that grazing may be a valid alternative to intensive rearing systems for growing heifer (Fig. 1), with no significant effects on the age of puberty and with interesting cost savings and reduced environmental impact (Sabia et al. 2014).

The dry phase is characterised by a higher use of straw and the inversion of the ratio of calcium to phosphorus. The use of agricultural by-products is not very frequent. However, the inclusion of dried stoned olive pomace in a ration for lactating buffaloes did not produce any significant difference in terms of milk yield while improving some qualitative parameters (Terramoccia et al. 2013). 


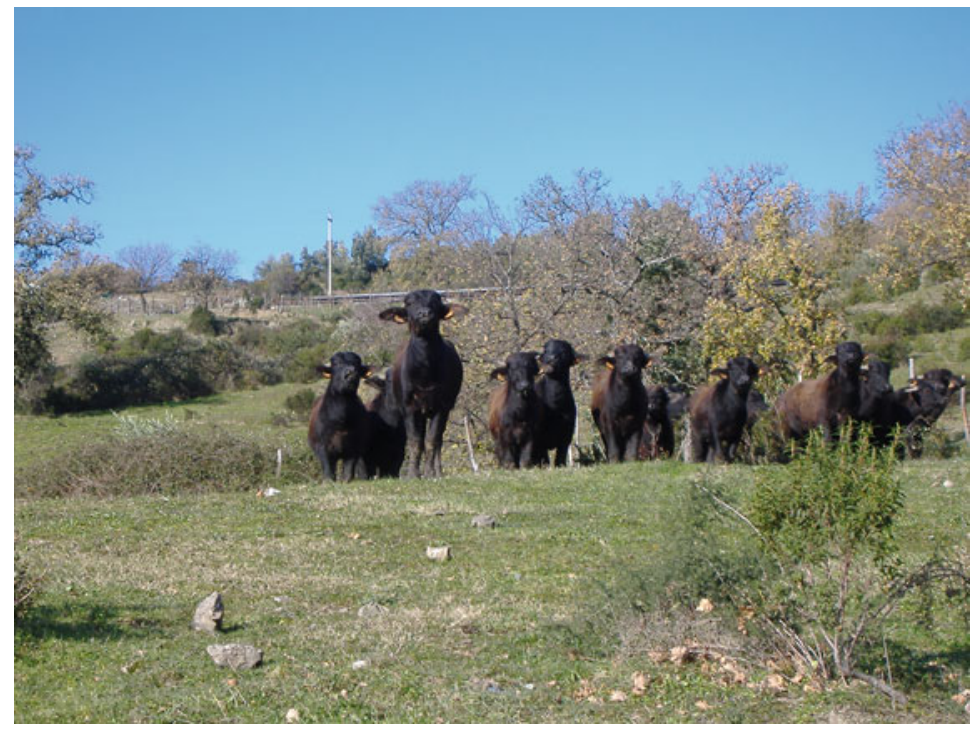

Fig. 1 Buffalo heifers grazing on a Mediterranean natural pasture

\subsection{Feeding Behaviour}

The dry matter intake of dairy buffaloes (16 kg DM/animal/day) is generally lower than that of dairy cattle (Terramoccia et al. 2005). However, these animals show a higher digestibility of protein and fibre as compared with cattle and sheep (Bartocci et al. 2005) with lower emissions in the environment. When kept on pasture, buffalo heifers show productive and reproductive performances similar to those shown by confined animals whose diet is based on mixed rations (Sabia et al. 2014). They eat a wide variety of plants, although they only occasionally ingest non-herbaceous plants; buffaloes are, therefore, considered grazers rather than browsers (Napolitano et al. 2007). The adaptation to a highly variable diet has also led to a high resistance to unbalanced diets, particularly in terms of protein excess; as a result, these animals are rarely affected by lameness of nutritional origin (Napolitano et al. 2013).

\section{Nutritional Requirements of Dairy Buffaloes}

The nutritional requirements of dairy buffaloes are influenced by several factors related, in particular, to the following three physiological stages: growing period (i.e. heifers), lactation period, dry period. In each phase, the identification of feeds with high nutrient digestibility could reduce the emissions resulting from enteric 
rumination and increase buffalo farming environmental sustainability (Sabia et al. 2015).

\subsection{Lactating Phase}

The standard lactation of buffalo cows is 270 days with an average milk production of about $2,200 \mathrm{~kg}$. The peak of maximum production is reached at 50-60 days from calving. Nutritional needs are related to the output of buffalo cows during lactation. The dry matter content of buffalo milk $(18.5 \%)$ is much higher than that of cow milk (Claps et al. 2007) and in order to standardise milk production according to fat and protein contents, Di Palo (1992) developed a specific equation. Using this equation Proto (1993) observed that for the production of $1 \mathrm{~kg}$ of standardised buffalo milk, 0.44 Milk Forage Unit (MFU) are necessary. According to Zicarelli (1999), the energy content of the feed ration for lactating buffaloes may vary from 0.85 to $0.90 \mathrm{MFU} / \mathrm{kg} \mathrm{DM}$ and the percentage of crude protein (CP) should be 14-15\%. In fact, this author suggests that $2.47 \mathrm{~g}$ of CP per $1 \mathrm{~g}$ of milk protein are acceptable levels for a balanced ration; while in early lactation, when the levels of dry matter intake are lower, this value should be increased by $10 \%$ (Campanile et al. 1995).

\subsection{Dry Phase}

The dry phase is the period between the end of lactation and the subsequent calving. Although this phase may be considered unproductive by farmers, it is fundamental to obtain satisfactory productive performances in the subsequent lactation. During this period, buffaloes should be provided with a ration capable to fulfil both maintenance requirements and the requirements for an optimal foetal growth, which are particularly high in the last months of pregnancy. The requirements recommended by Proto (1993) for the dry phase of buffaloes are about 0.65 MFU/ $\mathrm{kg}$ DM for energy and $10.5 \%$ for CP. In addition, Terramoccia et al. (2005) suggested the use of fresh forages or hay with high biological value and the integration with at least $15 \% / \mathrm{kg} \mathrm{DM}$ of concentrates. An appropriate ration for this phase should have a low rumen fermentation rate, which promotes the production of volatile fatty acids and improves the proliferation of cellulolytic bacteria. During this phase, a decrease of the absorption process with a drop in the rumen papillae activity is noticed. 


\subsection{Heifer Growth Phase}

In many countries growing heifers are reared exclusively on very poor pasture and hay. However, this is not the proper approach from an economic and animal welfare point of view, as the heifer has to reach puberty in the best physical condition. Thus, in order to reduce their unproductive period, heifers have to be fed with proper diets, to obtain high daily gains, and anticipate sexual maturity, conception and first calving. However, the studies on the rearing systems to be used to increase growth rates and reduce the age of puberty of buffalo heifers achieved contrasting results. Borghese et al. (1997), when comparing various intensive rearing systems at different energy levels with a pasture system, found that heifers fed a total mixed ration showed an earlier age of puberty compared with grazing animals. Conversely, Terzano et al. (1996) observed that grazing heifers reached puberty earlier than animals fed corn silage ad libitum, although the latter showed a higher weight at puberty. Similarly, Sabia et al. (2014) found no significant differences in terms of age of puberty between buffalo heifers reared in intensive or extensive conditions, although the weights of puberty were higher in confined animals.

\section{Sustainability of Dairy Buffalo Farming}

Water buffaloes, like other ruminants, are very efficient as they are able to convert feed with low nutritional quality into products with higher nutritional values. However, the contribution of methane derived from ruminal fermentations to agriculturally greenhouse gas emissions (GHG) has led to increasing efforts to develop strategies for the reduction of ruminant methane production (Martin et al. 2010). According to the Kyoto Protocol (1997), 37 industrialised countries and the European Community, during the first commitment, agreed to reduce GHG emissions to an average of $5 \%$ against 1,990 levels; during the second commitment period, parties agreed to reduce GHG emissions by at least $18 \%$ below 1,990 levels in the 8-year period from 2013 to 2020 . Livestock production is responsible for 8-10.8 \% of GHG emissions as assessed by International Panel of Climate Changes (IPCC). In Italy, according to the report of the Institute for the Protection and Environmental Research (ISPRA), the emission factor for enteric fermentation in buffaloes appears to be $38.4 \%$ less than the dairy cow, whereas for manure management the emission factor is $20.5 \%$ less in buffaloes compared with dairy cows (Cóndor et al. 2008).

However, few studies have been conducted on environmental impact assessment of dairy buffalo farms. Recently, Pirlo et al. (2014) observed that the environmental impact of dairy buffalo farms, expressed in terms of global warming, was $5.07 \mathrm{~kg}$ of $\mathrm{CO}_{2}$ eq per $1 \mathrm{~kg}$ of normalised buffalo milk. This value is nearly five times higher than that produced by dairy cow farms (O'Brien et al. 2012). This difference may be attributed to the fact that dairy buffalo farms require energy inputs for the 
production and the purchase of raw materials similar to those of dairy cows, but lower outputs in terms of milk production can be obtained. Another aspect of buffalo farming with a potentially high environmental impact is manure management. Faugno et al. (2012) found that buffalo manure has less nitrogen content than dairy cow manure. In addition, they suggested that immediate incorporation is the best technique of manure spreading in terms of sustainability, albeit more expensive. Martiniello et al. (2010) observed that the use of buffaloes manure increases dry matter yield of forage crops compared to traditional management as the carbonnitrogen ratio in buffalo manure is able to promote biomass production.

Sabia et al. (2014) suggested that the use of an extensive system based on grazing for some unproductive phases of animal rearing (e.g. heifer growth) could reduce the environmental impact of dairy buffalo farms. In particular, freeranging animals benefit from forages directly taken from pasture, thus potentially decreasing the emission of pollutants contributing to global warming, acidification and eutrophication potential, while also reducing non-renewable energy use. A further beneficial effect of buffalo heifer free-ranging system is the marked reduction in consumption of feed potentially edible by humans, as most of the plants growing in natural pastures are not directly usable in human nutrition. Obviously, buffalo heifer free-ranging system requires a higher level of land occupation. However, for marginal natural pastures there are no uses other than breeding of local ruminant species, which also implies a higher level of quality in land use (e.g. biodiversity conservation, animal welfare).

\section{Conclusion}

Buffalo farming is an emerging enterprise in Italy and other European and non-European countries in a dairy market progressively becoming saturated. Therefore, further studies are needed to assess the environmental impact of this species and identify alternative environmental friendly rearing techniques.

Open Access This chapter is distributed under the terms of the Creative Commons Attribution Noncommercial License, which permits any noncommercial use, distribution, and reproduction in any medium, provided the original author(s) and source are credited.

\section{References}

Bartocci S, Terramoccia S, Puppo S (2005) New acquisitions on the digestive physiology of the Mediterranean buffalo. In: Borghese A (ed) Buffalo production and research, REU technical series 67. FAO, Rome, pp 161-172

Borghese A, Barile VL, Ficco G, Galasso A, Marchiori E, Terzano GM (1997) Feeding system effect on reproduction performances in buffalo heifers. In: Proceedings 5th World Buffalo Congress, Caserta, Italy, 13-16 Oct, pp 697-701 
Campanile G, Di Palo R, Di Meo C, Boni R (1995) Effetti dell'integrazione di P durante l'asciutta sui livelli ematici di $\mathrm{Ca}, \mathrm{P} \mathrm{e} \mathrm{Mg}$ nella bufala. Paper presented at the 11th international ASPA congress, Italy, Grado 77-78

Claps S, Pizzillo M, Agoglia E, Scettino MV, Sabia E, Rubino R (2007) Chemical and texture characteristics and sensory properties of "mozzarella" cheese from different feeding systems. Ital J Anim Sci 6(2):1143-1146

Cóndor RD, Di Cristofaro E, De Laurentis R (2008) Agricoltura: inventario nazionale delle emissioni e disaggregazione provinciale. Istituto superiore per la protezione e la ricerca ambientale, ISPRA Rapporto tecnico 85/2008. Roma, Italia

Di Palo R (1992) Produzione lattea nella bufala con diete tradizionali e con l'impiego di acidi grassi. Research thesis, Fac Med Vet, Napoli, Italy

Faugno S, Pindozzi S, Infascelli R, Okello C, Ripa NM, Boccia L (2012) Assessment of nitrogen content in buffalo manure and land application costs. J Agr Eng 43(e13):86-92

Food and Agriculture Organization of the United Nations, Statistics Division (2013) http:// faostat3.fao.org/download/Q/QA/E. Accessed 10 Dec 2014

Helal FIS, Lasheen MA (2008) The Productive performance of Egyptian dairy buffaloes receiving biosynthetic bovine somatotropin (rbST) with or without monensin. Am Eurasian J Agric Environ Sci 3(5):771-777

Kyoto Protocol (1997) Kyoto protocol to the United States framework convention on climate changes. http://unfccc.int/resources/docs/convkp/kpeng.html

Martin C, Morgavi DP, Doreau M (2010) Methane mitigation in ruminants: from microbe to the farm scale. Animal 4:351-365

Martiniello P, Annicchiarico G, Sabia E, Terzano GM, Odoardi M, Pintus B, Pacelli C, Rossi E, Concetti S (2010) Utilization of buffalo's manure for forage production in sustainable agriculture. Rev Vet 21:817-819

Napolitano F, Grasso F, Saltamacchia F, Martiniello P, Bilancione A, Pacelli C, De Rosa G (2007) Grazing behaviour of buffalo heifers. Ital J Anim Sci 6(2):1256-1259

Napolitano F, Pacelli C, Grasso F, Braghieri A, De Rosa G (2013) The behaviour and welfare of buffaloes (Bubalus bubalis) in modern dairy enterprises. Animal 7:1704-1713

O'Brien D, Shalloo L, Patton J, Buckley F, Grainger C, Wallace M (2012) A life cycle assessment of seasonal grass-based and confinement dairy farms. Agric Syst 107:33-46

Pirlo G, Carè S, Fantin V, Falconi F, Buttol P, Terzano GM, Masoni P, Pacelli C (2014) Factors affecting life cycle assessment of milk produced in 6 Mediterranean buffalo farms. J Dairy Sci. http://dx.doi.org/10.3168/jds.2014-8007

Proto V (1993) L'alimentazione della bufala. In: Giornata di studio “Alimentazione zootecnica e qualità del latte bovino e bufalino", 29 Ottobre 1993, Eboli (SA), 1-42

Sabia E, Napolitano F, De Rosa G, Terzano GM, Barile VL, Braghieri A, Pacelli C (2014) Efficiency to reach age of puberty and behaviour of buffalo heifers (Bubalus bubalis) kept on pasture or in confinement. Animal 8(11):1907-1916

Sabia E, Claps S, Napolitano F, Annicchiarico G, Bruno A, Francaviglia R, Sepe L, Alenadri R (2015) In vivo digestibility of two different forage species inoculated with arbuscular mycorrhiza in Mediterranean red goats. Small Rumin Res 123:83-87

Terramoccia S, Bartocci S, Borghese A (2005) Nutritional requirements in buffalo cows and heifers. In: Borghese A (ed) Buffalo production and research. FAO, Rome, pp 145-160

Terramoccia S, Bartocci S, Taticchi A, Di Giovanni S, Pauselli M, Mourvaki E, Urbani S, Servilli M (2013) Use of dried stoned olive pomace in the feeding of lactating buffaloes: effect on the quantity and quality of the milk produced. Asian Australas J Anim Sci 26(7):971-980

Zicarelli L (1997) Reproductive seasonality in buffalo. Proceedings of the third course on biotechnology of reproduction in buffaloes, issue 2, Caserta, Italy, 6-10 Oct, pp 29-52

Zicarelli L (1999) Perspectives of buffalo husbandry in Brazil and Latin America. Funep, Jaboticabal, pp 157-178 